\title{
Candida golubevii sp. nov., an asexual yeast related to Metschnikowia lunata
}

\author{
Carlos A. Rosa, ${ }^{1}$ Sasitorn Jindamorakot, ${ }^{2}$ Savitree Limtong, ${ }^{3}$ \\ Takashi Nakase, ${ }^{4}$ Fernando C. Pagnocca ${ }^{5}$ and Marc-André Lachance ${ }^{6}$ \\ ${ }^{1}$ Departamento de Microbiologia, ICB, C.P. 486, Universidade Federal de Minas Gerais, Belo \\ Horizonte, MG 31270-901, Brazil \\ ${ }^{2}$ BIOTEC Culture Collection, National Center for Genetic Engineering and Biotechnology (BIOTEC), \\ 113 Paholyothin Road, Klong 1, Klong Luang, Pathumthani 12120, Thailand \\ ${ }^{3}$ Department of Microbiology, Faculty of Science, Kasetsart University, 50 Paholyothin Rd., Bangkok \\ 10900, Thailand \\ ${ }^{4}$ NITE Biological Resource Center (NBRC), National Institute of Technology and Evaluation, 2-5-8 \\ Kazusakamatari, Kisaraza, Chiba 292-0818, Japan \\ ${ }^{5}$ Departamento de Bioquímica e Microbiologia, Centro de Estudos de Insetos Sociais, Universidade \\ Estadual Paulista, Avenida 24 A, 1515, Rio Claro, SP 13506-900, Brazil \\ ${ }^{6}$ Department of Biology, University of Western Ontario, London, Ontario N6A 5B7, Canada
}

Correspondence

Carlos A. Rosa carlrosa@icb.ufmg.br
Metschnikowia lunata is the only described representative of its own subclade within the Metschnikowia clade (Mendonça-Hagler et al., 1993). The species was isolated from flowers and plant exudates and differs from other Metschnikowia species in forming lunate vegetative cells (Miller \& Phaff, 1998). Lachance et al. (2003) reported on the isolation of another subclade member (Candida sp. UWOPS 02-210.2/MAL-2003) from a flower of Ipomoea indica (Convolvulaceae) in Hawaii, but have not published a formal description. In the course of two independent studies of the yeast communities associated with insects and flowers in Thailand and Brazil, two isolates possessing lunate cells were also obtained. Sequencing of the D1/D2 domain of the large subunit rRNA gene showed that these yeasts represent a novel species related to $M$. lunata. The isolates did not produce ascospores when tested on several sporulation media, alone or mixed. In this paper, the novel species is named as Candida golubevii sp. nov., in honour of Dr Wladyslav I. Golubev in recognition of his contributions to yeast taxonomy in Russia.
Strain BCC $8332^{\mathrm{T}}$ (BCC, BIOTEC Culture Collection) was isolated from insect frass collected in Than-Tong waterfall, Nong Khai Province, Thailand, in February of 2001. Strain UFMG-C117A (UFMG, Culture Collection of Micro-organisms and Cells of the Universidade Federal de Minas Gerais) was obtained from a flower of Ipomoea sp. (Convolvulaceae) collected on the banks of the Paraguai River near the city of Corumbá, state of Mato Grosso do Sul, within the Pantanal ecosystem, Brazil, in February of 2002. The yeasts were isolated on yeast extract-malt extract agar (YMA; $1 \%$ glucose, $0.5 \%$ peptone, $0.3 \%$ yeast extract, $0.3 \%$ malt extract and $2 \%$ agar) containing $100 \mathrm{mg}$ chloramphenicol $\mathrm{l}^{-1}$. Sampling methods used were as described previously (Rosa et al., 2007). Plates were incubated at room temperature $\left(25 \pm 3{ }^{\circ} \mathrm{C}\right)$ for $3-$ 8 days. Each different yeast morphotype was purified and maintained on YMA agar slants or in liquid nitrogen for later identification. The yeasts were characterized by using standard methods (Yarrow, 1998). Identification followed the keys of Kurtzman \& Fell (1998).

The nucleotide sequences of the D1/D2 domain of the large subunit rDNA of the strain from Thailand were determined according to procedures described by Jindamorakot 
et al. (2008). The D1/D2 domains of the large subunit of the rDNA of the Brazilian strain were amplified by PCR directly from whole cells, as described previously (Lachance et al., 1999). The sequence was edited with the program DNAMAN, version 6.0 (Lynnon BioSoft). Existing sequences for other yeasts were retrieved from GenBank. The CLUSTAL $\mathrm{W}$ software (Thompson et al., 1994) incorporated in DNAMAN was used to align the sequences and construct a neighbour-joining tree with 1000 bootstrap iterations.

\section{Species delineation and ecology}

C. golubevii sp. nov. belongs to the Metschnikowia clade and is related to M. lunata (Fig. 1). These two species showed $10 \%$ divergence in the D1/D2 region of the rDNA large subunit. C. golubevii was also related to an undescribed Candida species (strain UWOPS 02-210.2/ MAL-2003) isolated from a flower of I. indica in Hawaii (Lachance et al., 2003), with which it differs by $9 \%$ sequence divergence in the same gene region. The D1/D2 sequences of the two isolates of C. golubevii were identical.

The habitat specificity of C. golubevii was not easily established as one strain was isolated from insect frass in Thailand and the other from a morning-glory flower in Brazil. The species might be associated with floricolous insects. The closest described relative of C. golubevii, $M$. lunata, was isolated from a flower of Vicia cracca (Fabaceae) in Russia and from an exudate of Casuarina sp. (Casuarinaceae) in Japan (Miller \& Phaff, 1998), also suggesting an association with the insect-plant interface. The isolation of C. golubevii in Thailand and Brazil suggests that it is rare, but widespread in tropical environments.

The two isolates of C. golubevii sp. nov. alone or mixed in pairs were examined after growth on the most common sporulation media at 17 and $25{ }^{\circ} \mathrm{C}$ (corn meal agar, dilute V8 agar, $5 \%$ malt extract agar, and yeast carbon base agar supplemented with $0.01 \%$ ammonium sulphate, among others), but asci or signs of conjugation were not seen.

\section{Latin diagnosis of Candida golubevii Rosa, Jindamorakot, Limtong, Nakase, Pagnocca et Lachance sp. nov.}

In medio liquido post dies tres cellulae singulae aut binae; cellulae ovoidae aut lunatae $(2-3 \times 2-5 \mu \mathrm{m})$. Post unum mensem sedimentum formatur. Cultura in agaro malti post dies 2 $\left(17^{\circ} \mathrm{C}\right)$ parva, convexa, glabra et candida. In agaro farinae Zea mays post dies 14 mycelium nec pseudomycelium non formantur. Glucosi fermentatur. Glucosum, galactosum, L-sorbosum, sucrosum, maltosum, cellobiosum, trehalosum, melezitosum, Dxylosum (lente), D-ribosum (lente), ethanolum (exigue lente), glycerolum, ribitolum (exigue lente), D-mannitolum, D-glucitolum, methyl $\alpha$-D-glucosidum, salicinum, acidum 2-ketogluconicum, acidum succinicum (variabile), xylitolum, acidum Dgluconicum (lente), D-glucosaminum (lente), $\mathrm{N}$-acetylglucosaminum et hexadecanum (lente) assimilantur, at non lactosum, melibiosum, raffinosum, inulinum, amylum solubile, L-arabinosum, D-arabinosum, L-rhamnosum, erythritolum, galactitolum, glucono- $\delta$-lactonum, acidum 5-ketogluconicum, acidum DLlacticum, acidum citricum, inositolum, acidum D-glucuronicum, acidum D-galacturonicum, L-arabinitolum, propanum-1,2-diolum, butanum-2,3-diolum, nec methanolum. Ethylaminum, lysinum et cadaverinum assimilantur at non natrium nitricum nec natrium nitrosum. Ad crescentiuam vitamina externa necessaria sunt. Augmentum in $37^{\circ} \mathrm{C}$ (variabile). Habitat insectum et flores in Thailand et Brazil. Typus BCC $8332^{\mathrm{T}}$ $\left(=\mathrm{CBS} 11362^{\mathrm{T}}=\mathrm{NBRC} 105679^{\mathrm{T}}\right)$. In collectione zymotica Centraalbureau voor Schimmelcultures.

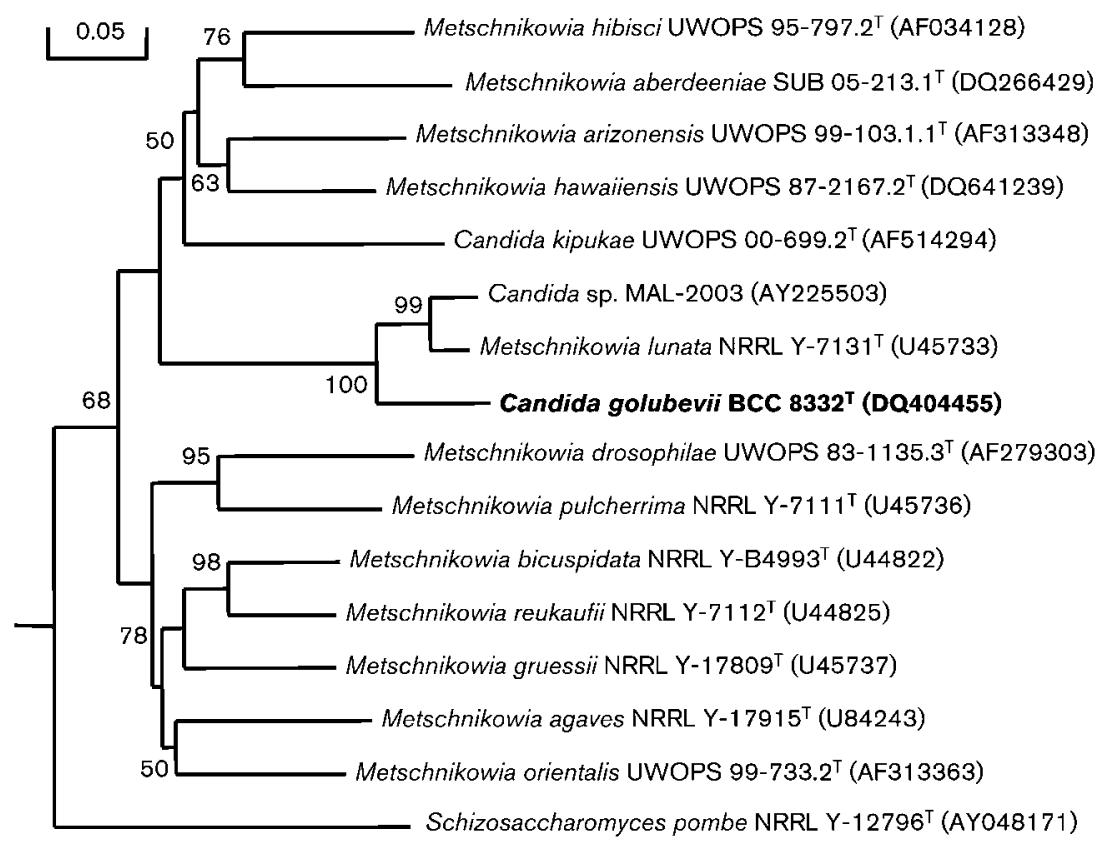

Fig. 1. Neighbour-joining tree showing the placement of Candida golubevii sp. nov. among related species in the Metschnikowiaceae clade. Bootstrap values of $50 \%$ and above are shown. Bar, 0.05 substitutions per nucleotide position. 


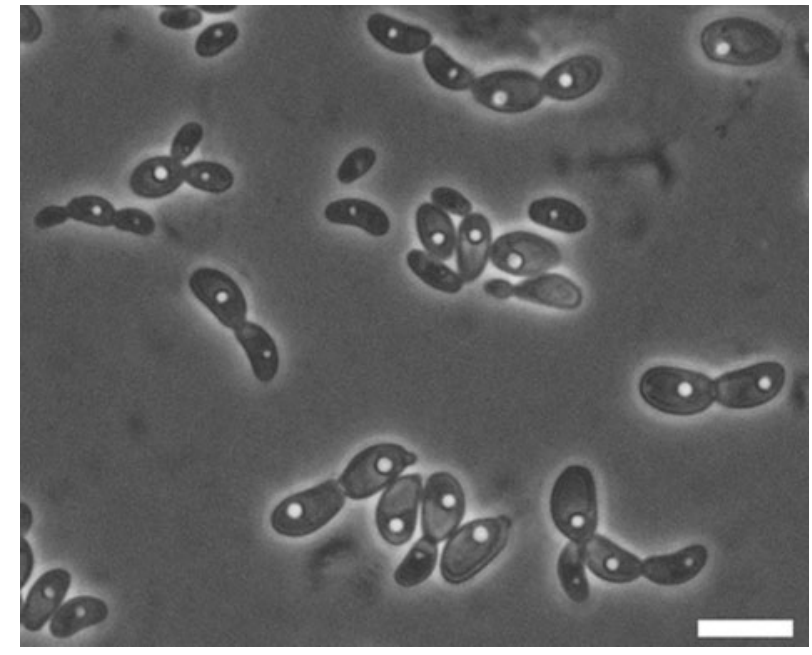

Fig. 2. Phase-contrast micrograph of budding cells of Candida golubevii BCC $8332^{\top}\left(=\mathrm{CBS} 11362^{\top}\right)$ on yeast carbon base agar (Difco) with $0.01 \%$ ammonium sulphate after 2 days at $20{ }^{\circ} \mathrm{C}$. Bar, $5 \mu \mathrm{m}$.

\section{Description of Candida golubevii Rosa, Jindamorakot, Limtong, Nakase, Pagnocca \& Lachance sp. nov.}

Candida golubevii (go.lu.be'vi.i. N.L. gen. masc. sing. n. golubevii of Golubev, in honour of Dr W. I. Golubev for his contributions to yeast taxonomy).

In yeast extract $(0.5 \%)$, glucose $(2 \%)$ broth after 3 days at $25^{\circ} \mathrm{C}$, the cells are ovoid to lunate $(2-3 \times 2-5 \mu \mathrm{m})$. Budding is multilateral (Fig. 2). A sediment is formed after a month, but no pellicle is observed. On YMA agar after 2 days at $17{ }^{\circ} \mathrm{C}$, colonies are white, convex, smooth and opalescent. In Dalmau plates after 2 weeks on cornmeal agar, pseudomycelia or true mycelia are not formed, but chains of budding cells are sometimes present. Fermentation of glucose is positive and galactose variable. Maltose, cellobiose, trehalose, melezitose, D-xylose and methyl $\alpha$-D-glucoside are not fermented. Assimilation of carbon compounds: glucose, galactose, L-sorbose, sucrose, maltose, cellobiose, trehalose, melezitose, D-xylose (delayed), D-ribose (delayed), ethanol (weak delayed), glycerol, ribitol (weak delayed), D-mannitol, D-glucitol, methyl $\alpha$-D-glucoside, salicin, 2-ketogluconic acid, succinic acid (variable), xylitol, D-gluconic acid (delayed), Dglucosamine (delayed), $\mathrm{N}$-acetyl-D-glucosamine and hexadecane (delayed) are assimilated. No growth occurs on lactose, melibiose, raffinose, inulin, soluble starch, Larabinose, D-arabinose, L-rhamnose, erythritol, galactitol, glucono- $\delta$-lactone, 5-ketogluconic acid, DL-lactic acid, citric acid, inositol, D-glucuronic acid, D-galacturonic acid, L-arabinitol, propane-1,2-diol, butane-2,3-diol or methanol. Assimilation of nitrogen compounds: positive for lysine, ethylamine- $\mathrm{HCl}$ and cadaverine, and negative for nitrate and nitrite. Growth in vitamin-free medium is negative; biotin and thiamine are required. Growth in amino-acid-free medium is positive. Growth at $37^{\circ} \mathrm{C}$ is variable. Growth on YMA agar with $10 \%$ sodium chloride is positive. Growth in $50 \%$ glucose/yeast extract $(0.5 \%)$ is weak to strong. Starch-like compounds are not produced. In $100 \mu \mathrm{g}$ cycloheximide $\mathrm{ml}^{-1}$ growth is negative. Urease activity is negative. Diazonium Blue B reaction is negative. Habitat is insect frass and flower of Ipomoea sp. in Thailand and Brazil, respectively.

The type strain is BCC $8332^{\mathrm{T}}\left(=\mathrm{CBS} 11362^{\mathrm{T}}=\mathrm{NBRC}\right.$ $\left.105679^{\mathrm{T}}\right]$, isolated from insect frass collected in Than-Tong waterfall, Nong Khai Province, Thailand.

\section{Acknowledgements}

This work was funded by Conselho Nacional de Desenvolvimento Cientifico e Tecnológico ( $\mathrm{CNPq}$ - Brazil), Fundação do Amparo a Pesquisa do Estado de Minas Gerais (FAPEMIG), and the Natural Science and Engineering Research Council of Canada (M.-A. L.).

\section{References}

Jindamorakot, S., Limtong, S., Yongmanitchai, W., Tuntirugkii, M., Potacharoen, W., Kawasaki, H., Tantichaoen, M. \& Nakase, T. (2008). Candida ratchasimensis sp. nov. and Candida khaoyaiensis sp. nov., two anamorphic yeast species isolated from flowers in Thailand. FEMS Yeast Res 8, 955-960.

Kurtzman, C. P. \& Fell, J. W. (1998). The Yeasts, a Taxonomic Study, 4th edn. Amsterdam: Elsevier.

Lachance, M. A., Bowles, J. M., Starmer, W. T. \& Barker, J. S. F. (1999). Kodamaea kakaduensis and Candida tolerans, two new ascomycetous yeast species from Australian Hibiscus flowers. Can J Microbiol 45, 172-177.

Lachance, M. A., Bowles, J. M. \& Starmer, W. T. (2003). Geography and niche occupancy as determinants of yeast biodiversity: the yeastinsect-morning glory ecosystem of Kípuka Puaulu, Hawai'i. FEMS Yeast Res 4, 105-111.

Mendonça-Hagler, L. C., Hagler, A. N. \& Kurtzman, C. P. (1993). Phylogeny of Metschnikowia species estimated from partial rRNA sequences. Int J Syst Bacteriol 43, 368-373.

Miller, M. W. \& Phaff, H. J. (1998). Metschnikowia Kamienski. In The Yeasts, a Taxonomic Study, 4th edn, pp. 256-267. Edited by C. P. Kurtzman \& J. W. Fell. Amsterdam: Elsevier.

Rosa, C. A., Pagnocca, F. C., Lachance, M.-A., Ruivo, C. C. C., Medeiros, A. O., Pimentel, M. R. C., Fontenelle, J. C. R. \& Martins, R. P. (2007). Candida flosculorum sp. nov. and Candida floris sp. nov., two yeast species associated with tropical flowers. Int J Syst Evol Microbiol 57, 2970-2974.

Thompson, J. D., Higgins, D. G. \& Gibson, T. J. (1994). ClUSTAL W: improving the sensitivity of progressive multiple sequence alignment through sequence weighting, position-specific gap penalties and weight matrix choice. Nucleic Acids Res 22, 4673-4680.

Yarrow, D. (1998). Methods for the isolation and identification of yeasts. In The Yeasts, a Taxonomic Study, 4th edn, pp. 77-100. Edited by C. P. Kurtzman \& J. W. Fell. Amsterdam: Elsevier. 